\title{
Fos-Jun interaction: mutational analysis of the leucine zipper domain of both proteins
}

\author{
Lynn J. Ransone, Jane Visvader, Paolo Sassone-Corsi, ${ }^{1}$ and Inder M. Verma \\ Molecular Biology and Virology Laboratory, The Salk Institute, San Diego, California 92138 USA
}

\begin{abstract}
Jun and Fos oncoproteins form a complex that regulates transcription from promoters containing AP-1 binding sites. The 'leucine zipper' domain of both Fos and Jun is necessary for the formation of the heterodimer, but the role of specific leucine residues is unclear. We have used site-specific mutagenesis to examine the contribution of individual leucine residues to the formation of a stable Fos-Jun protein complex and the binding of this complex to the AP-1 site. Mutation of a single leucine in either Fos or Jun had no effect on protein complex formation. Furthermore, mutations of two consecutive leucines in Jun did not interfere with heterodimer formation; however, in the case of Fos, two consecutive mutations resulted in an inability to form a heterodimer. Although mutagenesis of the first leucine of the heptad repeat had no effect on protein complex formation, this mutation in either Fos or Jun drastically reduced the affinity of the complex for DNA. Thus, both Fos and Jun contribute directly to the DNA-binding potential of the heterodimer.
\end{abstract}

[Key Words: Transcription factors; TPA-responsive element; heptad repeat; nuclear oncogenes]

Received March 9, 1989; revised version accepted April 10, 1989.

The products of the two nuclear proto-oncogenes c-fos and c-jun (AP-1) form a noncovalent association in some transcriptional complexes (Chiu et al. 1988; Rauscher et al. 1988b; Sassone-Corsi et al. 1988b|. AP-1 was first characterized as a nuclear factor that recognized the enhancer elements of SV40, the human metallothionein IIA gene, and the control regions of genes containing TPA (12-O-tetra-decanoylphorbol-13-acetate)-responsive promoter elements (TREs) (Angel et al. 1987; Lee et al. 1987b). The consensus core DNA sequence TGACTCA, the binding site of AP-1, has been found with several negative and positive transcriptional regulatory elements (Piette and Yaniv 1987; Franza et al. 1988; Rauscher et al. 1988a) and is recognized also by the products of both c-jun (Bohmann et al. 1987) and v-jun (Bos et al. 1988). AP-1, biochemically purified via its specific DNA-binding activity, was shown to contain several polypeptides ranging in size from 35 to $50 \mathrm{kD}$ (Lee et al. 1987a; Rauscher et al. 1988b). The major polypeptide species appears to be antigenically and biochemically related to the product of proto-oncogene c-jun, the cellular homolog of the transforming gene of avian sarcoma virus 17 (Bohmann et al. 1987; Maki et al. 1987; Angel et al. 1988; Lamph et al. 1988; Ryder and Nathans 1988; Ryseck et al. 1988). The Jun/AP-1 nuclear protein contains a region of homology to the DNA-binding domain of the yeast transcription factor GCN4 (Vogt et al. 1987), known to bind as a dimer to a target sequence identical

1Present address: Laboratorie de Genetique Moleculaire des Eucaryotes, Centre National de la Recherche Scientifique, 67085 Strasbourg, France. to an AP-1-binding motif (Hope and Struhl 1987). Recently, other yeast proteins have been identified that recognize the same binding site (Harshman et al. 1988; Jones et al. 1988). In addition, the DNA-binding domains of AP-1 and GCN4 are functionally equivalent, as they are interchangeable in yeast (Struhl 1987).

The fos oncogene ( $\mathrm{v}$-fos) was detected originally in $\mathrm{FB}$ ) and FBR murine sarcoma viruses (Curran et al. 1982; Curran and Verma 1984; Verma 1986). The c-fos product is a nuclear protein that undergoes extensive post-translational modification and forms a protein complex with a 39-kD nuclear protein (p39) (Curran and Teich 1982; Curran et al. 1984, 1985). The Fos protein participates in a nuclear protein complex with a sequence element upstream of several promoter control regions, including the adipocyte differentiation-sensitive gene $a P 2$ (Distel et al. 1987), the enhancer element from the long terminal repeats of human immunodeficiency virus (Franza et al. 1988), and the c-fos promoter (Sassone-Corsi et al. 1988a). In some of these cases, the Fos protein also has been reported to act as a positive trans-regulator of transcription. The Fos protein also has been reported to act as a positive trans-regulator (Setoyama et al. 1986; Lucibello et al. 1988; Sassone-Corsi et al. 1988a), indicating that it has pleiotrophic activity, depending on the nature of the transcriptional nucleoprotein complex. The DNA sequence of the adipocyte differentiation regulatory element is similar to that of the Jun/AP-1-binding site (Franza et al. 1988; Rauscher et al. 1988a), suggesting that Jun could be part of the Fos protein complex. In fact, the Fos-associated p39 protein was shown recently to be 
immunologically and structurally related to AP-1/Jun (Chiu et al. 1988; Rauscher et al. 1988b; Sassone-Corsi et al. 1988b). Furthermore, cooperation between these two nuclear oncoproteins was shown to be required for full activation of transcription from a TRE in transfected mammalian cells (Chiu et al. 1988; Sassone-Corsi et al. 1988b).

Several groups have demonstrated that Fos directly modulates Jun function by formation of a heterodimer of Fos and Jun proteins (Halazonetis et al. 1988; Kouzarides and Ziff 1988; Nakabeppu et al. 1988; Sassone-Corsi et al. 1988c; Rauscher et al. 1989|. A model proposed by Landschultz et al. (1988a) to explain how some DNAbinding proteins may form dimers postulates that a region of the protein, when arranged in an idealized $\alpha$ helix, forms a domain containing a periodic repetition of leucine residues. These leucines occur at every seventh residue over a distance of eight helical turns, which align along one face of the protein. Such a sequence is present in a number of known or probable transcription factors such as Fos, Jun, and GCN4 (Landschultz et al. 1988a). The model also proposes that the leucine sidechains extending from one $\alpha$-helix interdigitate with those displayed from a similar $\alpha$-helix of a second polypeptide, facilitating dimerization through strong hydrophobic interactions. They suggest that this hypothetical structure, referred to as the 'leucine zipper,' facilitates the formation of protein dimers. Recently, we have demonstrated that the Fos leucine zipper domain is necessary for the DNA-binding activity of the Fos-Jun heterodimer (Sassone-Corsi et al. 1988c). In this paper, we demonstrate that the leucine zipper domain of Jun is also essential for heterodimer formation. Mutagenic analysis of these leucine residues (converted to valine) in both Fos and Jun supports the hypothesis that this region is important in promoting stable interaction between the two proteins. In vitro protein-binding studies with a series of Fos and Jun mutants, together with a combination of mutants of both proteins, showed that multiple mutations in both Fos and Jun are necessary to affect protein association. Furthermore, we report that the mutagenesis of the first leucine of either the Fos or the Jun leucine zipper domain has no effect on heterodimer formation but plays a crucial role in DNA binding.

\section{Results \\ In vitro translation of Fos and Iun leucine zipper mutants}

Previously, we found that Fos protein directly modulates Jun function, probably through the formation of a heterodimer of Fos and Jun proteins. We also demonstrated that the DNA binding of the Fos-Jun complex requires the Fos leucine zipper domain (Sassone-Corsi et al. $1988 \mathrm{c})$. To further define the role of this region in the Fos-Jun interaction, we mutated individual leucines within the leucine zipper domain of both proteins.

Each of the five leucines in the Fos leucine zipper (Fos Leu-165, Leu-172, Leu-179, Leu-186, and Leu-193) was changed individually to conservative amino acid valine to generate mutants Fos L1-Fos L5 (see Fig. 1). Two double mutants were generated also. One, Fos L $2 / 3$, has

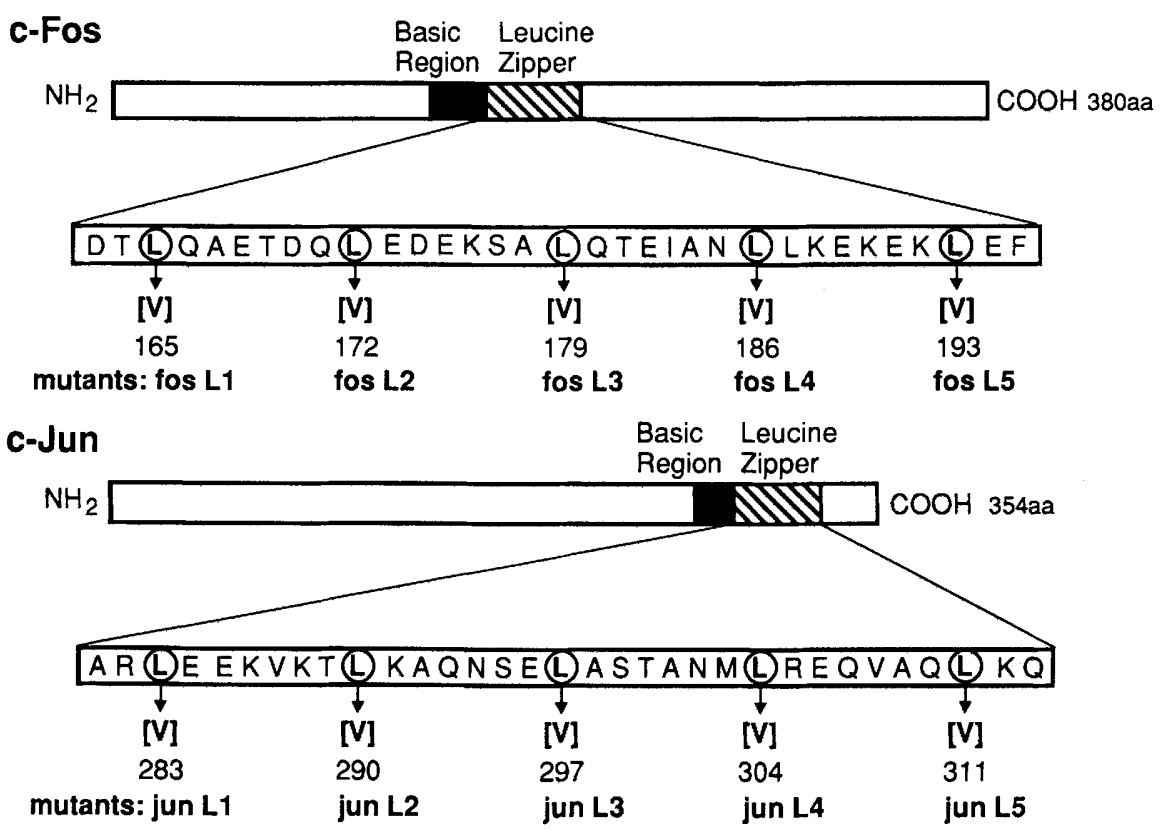

Figure 1. Structure of the Fos and Jun proteins. Schematic representation of the Fos and Jun proteins showing the basic region and leucine repeat domains. (Open boxes) The primary amino acid sequence of Fos and Jun. (Solid boxes) The basic motifs that contain a region of highly conserved basic residues proposed to be part of the DNA-binding domain. The leucine zipper structures (hatched boxes) have been enlarged to show the sequence of the region. The specific mutations from leucine to valine and the mutants generated with each change are indicated below each sequence. 
both Leu-172 and Leu-179 changed to valine, whereas the other, Fos L3/4, has valines at positions Leu-179 and Leu-186, respectively.

Similar mutations were generated in Jun. Individual leucines (Jun Leu-283, Leu-290, Leu-297, Leu-304, and Leu-311) were changed to valine to generate mutants Jun L1-Jun L5 (Fig. 1). Three additional valine double mutations were also made at positions Leu-283 and Leu-290, Leu-297 and Leu-304, and Leu-304, and Leu-311 to generate mutants Jun $\mathrm{L} 1 / 2$, Jun $\mathrm{L} 3 / 4$, and Jun $\mathrm{L} 4 / 5$, respectively. One mutant (designated Jun $\Delta(\mathrm{L} 1-\mathrm{L} 5)$ contained an in-frame deletion of the entire leucine zipper domain. All of the proteins were synthesized in vitro in the presence of $\left.{ }^{35} \mathrm{~S}\right]$ methionine and migrated on an SDS-polyacrylamide gel in accordance with their apparent molecular mass (Fig. 2). The translation efficiency of each of the mutated Fos (Fig. 2A) and Jun (Fig. 2B) proteins was comparable to that of the wild type.

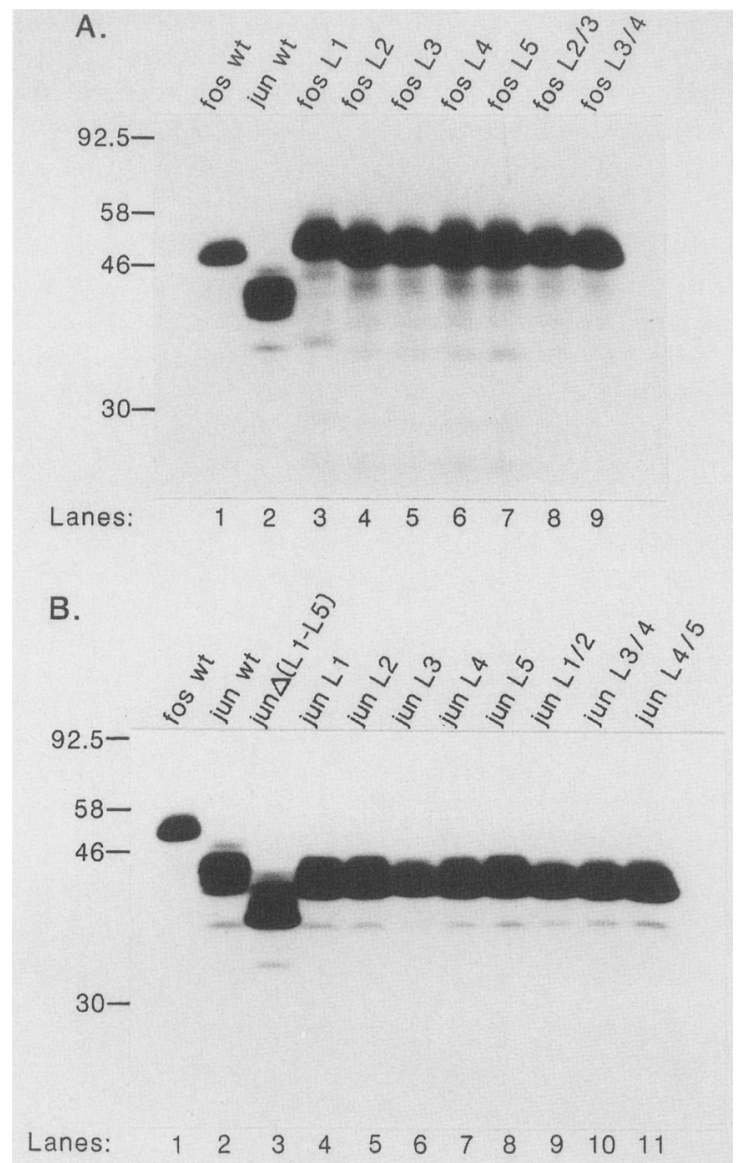

Figure 2. In vitro-translated Fos and Jun mutant proteins. SDS-PAGE of ${ }^{35} S \mid$ methionine-labeled in vitro-translated proteins. One microgram of RNA prepared by transcription of cDNA was translated in the presence of $\left.{ }^{35} S\right]$ methionine. Translation products were subjected to $12.5 \%$ SDS-PAGE. The positions of standard molecular weight protein markers are indicated. $(A)$ Five microliters of each Fos site-specific mutant plus both Fos and Jun wild-type (wt) proteins; $(B) 5 \mu \mathrm{l}$ of each Jun site-specific and deletion mutant plus both Fos and Jun wild-type proteins. Both Fos and Jun mutant and wild-type proteins are of the correct apparent molecular mass.
A single mutation in the leucine zipper does not alter Fos-Jun protein association

The $\left[{ }^{35} \mathrm{~S}\right]$ methionine-labeled mutant Fos proteins were assayed for complex formation with in vitro-synthesized wild-type Jun. Figure $3 \mathrm{~A}$ shows that the mutation of an individual leucine residue in Fos to valine does not affect complex formation (cf. lane 1 to lanes 2-6). However, the double mutations in Fos L2/3 or L3/4 (lanes 7 and 8 ), under similar conditions, eliminate the ability of the Fos protein to form an immunoprecipitable complex with Jun. It is possible that Fos M2 antibody may be unable to detect some Fos-Jun heterodimers; therefore, complex formation of the Fos double mutants with wild-type Jun also was assayed with the Fos monoclonal antibodies 18H6 and 14Cl (De Togni et al. 1988), which yielded similar results (data not shown).

The ${ }^{35} S \mid m e t h i o n i n e-l a b e l e d$ mutant Jun proteins then were assayed for their ability to complex with wild-type

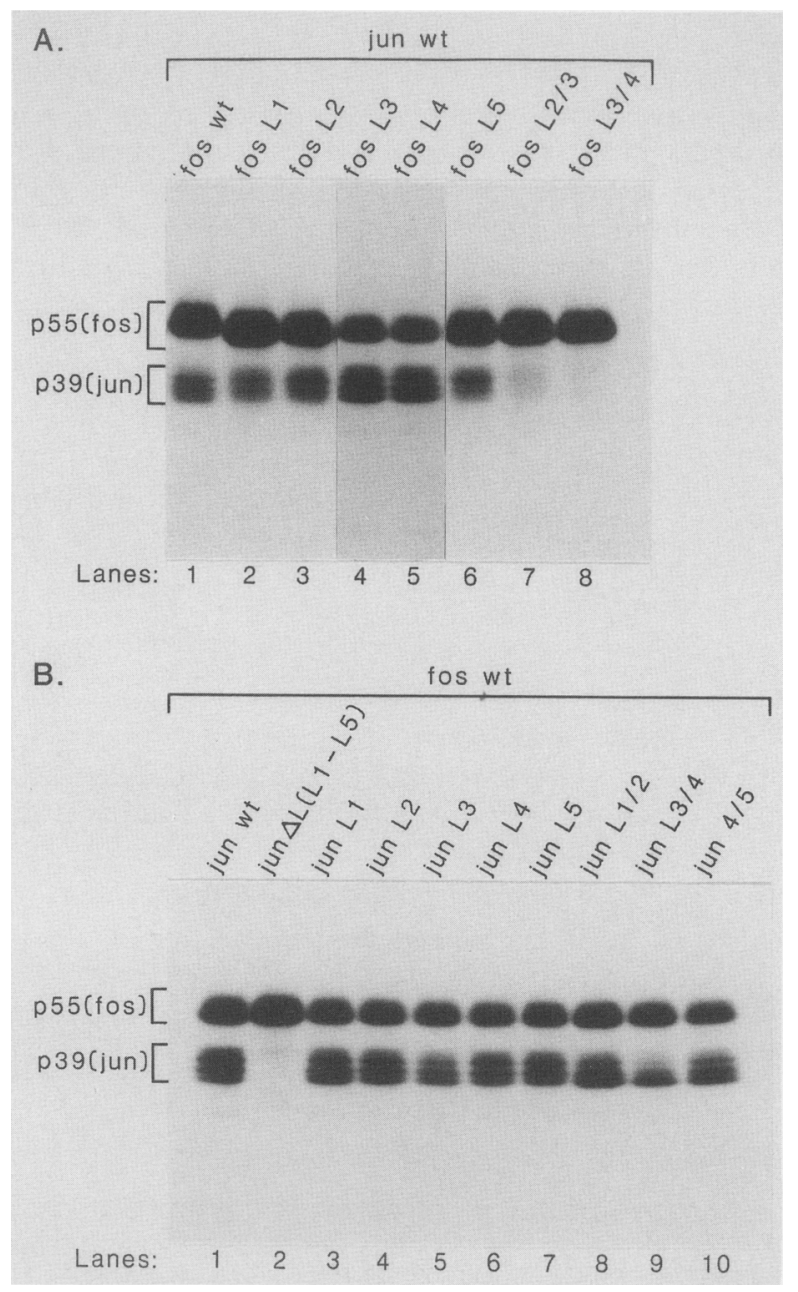

Figure 3. Interaction of mutated Fos and Jun proteins. Fos and Jun wild-type and mutant proteins labeled with [ ${ }^{35} S \mid$ methionine were synthesized in vitro, mixed, and immunoprecipitated with anti-Fos $\mathrm{M} 2 \mathrm{Ab}$. $(A)$ Jun wild-type $(\mathrm{wt})$ protein mixed with Fos wild-type and mutant proteins; $(B)$ Fos wild-type protein mixed with Jun wild-type and mutant proteins. The positions of both the Fos and Jun proteins are indicated. 
Fos protein. Figure 3B shows that a deletion of the entire leucine zipper domain in Jun [Jun $\Delta(\mathrm{L} 1-\mathrm{L} 5)$ ] eliminates its ability to bind and to form a stable immunoprecipitable complex with Fos (lane 2). However, mutation of individual or two consecutive leucines in the same region has no affect on Fos-Jun complex formation (lanes $3-8,10$ ) except for a slight dimunition with mutant Jun L3/4 (lane 9). These data demonstrate that although mutations of individual leucines in both Fos and Jun have no affect on heterodimer formation, the mutation of two consecutive leucines in Fos, but not Jun, prevents complex formation. Furthermore, Jun, like Fos (SassoneCorsi et al. 1988c), absolutely requires an intact leucine zipper domain for stable heterodimer formation.

DNA binding of the Fos-Iun complex is abolished by a single mutation in the leucine zipper

Previous studies have demonstrated that Fos and Jun bind DNA cooperatively (Halazonetis et al. 1988; Kouzarides and Ziff 1988; Nakabeppu et al. 1988; SassoneCorsi et al. 1988c; Rauscher et al. 1989. Therefore, we were interested in determining whether the seven mutant Fos proteins could cooperate with wild-type Jun in binding to the TRE, TGACTCA (Angel et al. 1987; Lee et al. 1987b). As shown in Figure 4A, the single amino acid change in Fos L1 abolishes the DNA-binding ca- pacity of the Fos-Jun complex (cf. lanes 1 and 2). It is worth noting that this mutation is adjacent to a region of basic residues that are conserved in Fos, Jun, and GCN4 (van Straaten et al. 1983; Struhl 1987; Lamph et al. 1988) and thought to be involved in DNA binding of Jun, GCN4, and C/EBP dimers to their respective target sequences (Struhl 1987, 1988; Landschultz et al. 1988b). The mutant Fos L2 displays slightly lower DNA binding in the presence of Jun, as compared to wild-type Fos levels (lanes 1 and 3 ), whereas a single mutation from leucine to valine in mutants Fos L3-L5 does not alter their ability to contribute to DNA binding (lanes 4-6). Mutations in consecutive leucines (Fos L $2 / 3$ and Fos L4/5) that prevented coimmunoprecipitation of Jun with Fos antibodies, however, showed $5-20 \%$ of the wildtype binding to TRE (lanes 7 and 8). It should be pointed out that the immunoprecipitation following the proteinbinding reactions are performed in the presence of detergent, whereas the protein/DNA-binding reactions are devoid of detergent (see Experimental procedures). Therefore, it is possible that detergent disrupts the weak dimeric complex that presumably forms to enable DNA binding. Furthermore, the presence of TRE may stabilize the protein complex, although addition of unlabeled TRE in the immunoprecipitation reaction had no affect on protein association (data not shown).

Having established that changes in the Fos leucine

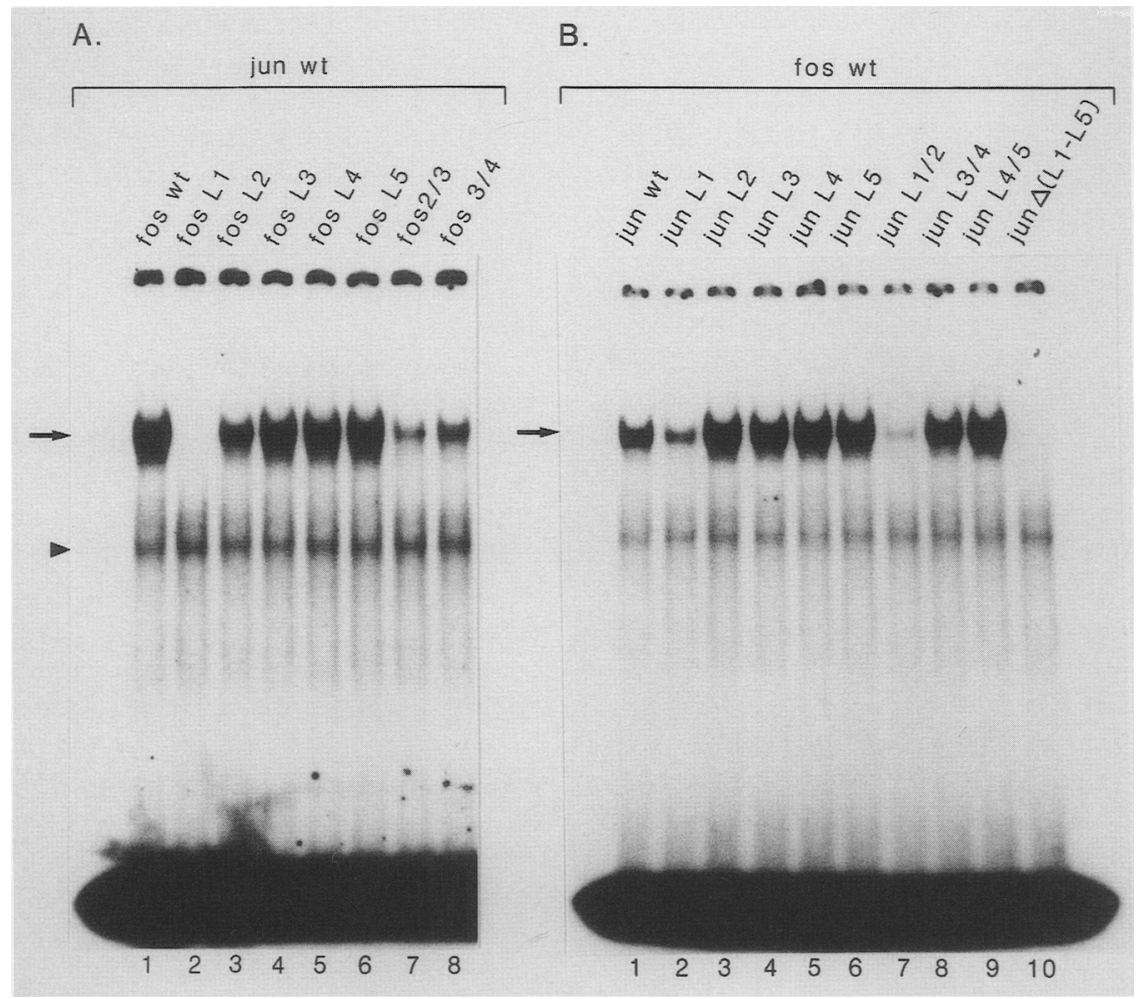

Figure 4. DNA binding with Fos-Jun heterodimer: gel retardation analysis. TRE labeled with ${ }^{32} \mathrm{P}$ was incubated prior to gel electrophoresis and autoradiography with unlabeled translation products of mixtures of the wild-type and mutant Fos and Jun proteins. (A) Jun wild-type (wt) protein mixed with each Fos mutant; $(B)$ Fos wild-type protein mixed with each Jun mutant. The Fos-Jun DNA complex is indicated by an arrow. The lower band (arrowhead) is related to nonspecific binding of proteins from the reticulocyte lysate. 
zipper domain can affect the DNA-binding potential of the Fos-Jun complex, we asked whether similar changes in the Jun protein might change its ability to cooperate with Fos in DNA binding. As shown in Figure $4 \mathrm{~B}$, the Jun $\Delta(\mathrm{L} 1-\mathrm{L} 5)$ mutant is incapable of cooperating with wild-type Fos in binding to the TRE (lane 10). The single mutation in Jun L1 diminishes DNA binding (cf. lanes 1 and 2), as observed with the Fos L1 or Fos L2 mutants. It should be emphasized that all three of these mutants (Fos L1, Fos L2, and Jun L1) were capable of forming a Fos-Jun protein complex that could be immunoprecipitated with Fos antibodies. Each of the other single mutations in Jun display wild-type DNA-binding activity in the presence of Fos. A mutation of the first two consecutive leucines, Jun L1/2, decreases DNAbinding activity below that of either of the two single mutations alone (cf. lane 7 to lanes 2 and 3), whereas changes in Jun L3/4 or Jun L4/5 have no such affect (lanes 8 and 9).

\section{Influence of single mutations in both Fos and Jun on heterodimer formation}

Because single mutations in either Fos or Jun, when tested with the appropriate wild-type protein, had no affect on Jun-Fos protein association (Fig. 3), we next asked whether a combination of mutations in both proteins would affect heterodimer formation. Each Fos mutant protein (Fos L1, L2, L4, L5, Fos L2/3, and Fos L3/4) was translated in vitro and assayed for its ability to form an immunoprecipitable complex with each of the in vitro synthesized Jun mutant proteins (Jun L1-L5, Jun L1/2, Jun L3/4, and Jun L4/5). Complex formation between each of the mutant proteins was compared to that of wild-type proteins (Fig. 5A, lane C). Jun mutants L1, L2, L4, L5 were able to complex with every Fos mutant containing a single amino acid change at levels comparable to that of wild-type Jun (cf. Fig. 5A,C-E, lanes 1, 2 and 4, 5 and Fig. 5A, lane $C$ ), except with Fos $\mathrm{L} 2$, where the levels of protein-protein interaction were reduced to $\sim 50 \%$ of the wild-type level, as determined by densitometric scanning. Jun L3, which complexed with wild-type Fos protein in both protein-binding (Fig. 3B, lane 5) and DNA-binding assays (Fig. 4B, lane 4), was able to form only a weak complex $(5-20 \%$ of the wildtype levels) with Fos mutant proteins L1-L5 (Fig. 5A-E, lanes $3 \mathrm{E}$ ). If Jun $\mathrm{L} 3$ and Fos mutant proteins were immunoprecipitated in RIPA buffer without SDS, the absolute levels of Jun bound in the complex increased approximately twofold, but were still three- to fourfold lower than those observed with other mutants /data not shown). These results suggest that the Jun L3-Fos mutant complex can form but is less stable to detergents than the wild-type heterodimer.

The protein-binding affinity of the Jun double mutants to each of the Fos mutants was impaired, with the exception of Jun L4/5, which complexed with Fos L3, L4, and L5 at nearly wild-type levels (Fig. 5C-E, lanes 8E). The degree of protein association varied greatly from apparently little or no association, such as Jun L1/2 and
L3/4 with Fos L4 and Fos L5 (Fig. 5D,E, lanes 6 and 7) to diminished binding seen with these same Jun mutants with Fos L3 (Fig. 5C, lanes 6 and 7). On the other hand, each of the Fos double mutants was unable to associate with any of the jun mutants tested (Fig. 5F,G). This result is in agreement with the protein-binding data obtained with these mutants with the wild-type Fos (Fig. $3 \mathrm{~A}$, lanes 7 and 81 .

\section{The effect of mutations in the leucine zipper of both Fos and Jun on DNA binding}

Analysis of the DNA-binding activity of Fos mutants L1-L5 revealed that although Fos L1 could complex to the Jun wild-type protein, it was unable to cooperate in binding to the TRE (Fig. 4A, lane 2). Furthermore, Fos L2 (Fig. 4A, lane 3) also displayed decreased levels of DNA binding in the presence of wild-type Jun, despite normal Jun-Fos protein interaction (Fig. 3A, lane 3). These data suggested that there was not always a direct correlation between protein association and the ability to bind to DNA. Therefore, we tested all possible combinations of the Fos and Jun mutants for DNA binding (Fig. 6). As expected, Fos L1 was unable to cooperate with any of the Jun mutants tested for DNA binding (Fig. 6A). Likewise, Jun L1, which had decreased DNA binding in the presence of wild-type Fos (Fig. 4B, lane 2), was unable to bind DNA efficiently in the presence of Fos L4 and Fos L5 (Fig. 6D,E, lanes 1) and displayed no DNA-binding activity in the presence of the other Fos mutants (Fig. $6 \mathrm{~B}, \mathrm{C}, \mathrm{E}, \mathrm{F}, \mathrm{G})$. Jun $\mathrm{L} 3$ was capable of cooperating with Fos L4 and L5 in binding to DNA, despite poor formation of a stable immunoprecipitable complex with these same mutant proteins (Fig. 6D,E, lanes 3; cf. Fig. 5D,E, lanes 3). In contrast, the DNA-binding activity of Jun L3 with Fos L2 (Fig. 6B, lane 3) was decreased, as expected from its inability to form a stable protein complex (Fig. 5B, lane 3).

Similar results were found with the Jun double mutants. Jun L1/2 was able to form a complex with Fos L1, Fos L2, and Fos L3 proteins but was unable to cooperate with these same proteins in binding to the TRE (Fig. $6 \mathrm{~A}-\mathrm{C}$, lanes 6 . These results are not completely unexpected, because Jun L1/2 displays decreased DNAbinding activity even in the presence of wild-type fos (Fig. 3B, lane 7). Jun L3/4 and Jun L4/5 display DNAbinding activities that are reflected in their ability to associate commensurately with each Fos mutant protein. Neither Jun L3/4 nor Jun L4/5 was capable of cooperating with Fos L2 in DNA binding (Fig. 6B, lanes 7 and 8 ), yet Jun L4/5 in the presence of Fos L4 or Fos L5 bound to the TRE at nearly wild-type levels (Fig. 6D,E, lanes 8). Jun L3/4 also cooperated in DNA binding with these same Fos mutants, although at much lower levels as compared with wild-type Fos and Jun proteins (Fig. 6D,E, cf. lane $C$ and lane 71.

The DNA-binding activity of the Fos double mutants in the presence of Jun wild-type protein was $\sim 25 \%$ of wild-type levels, despite the fact that there was no detectable protein association (Figs. 3A and 4A). These re- 


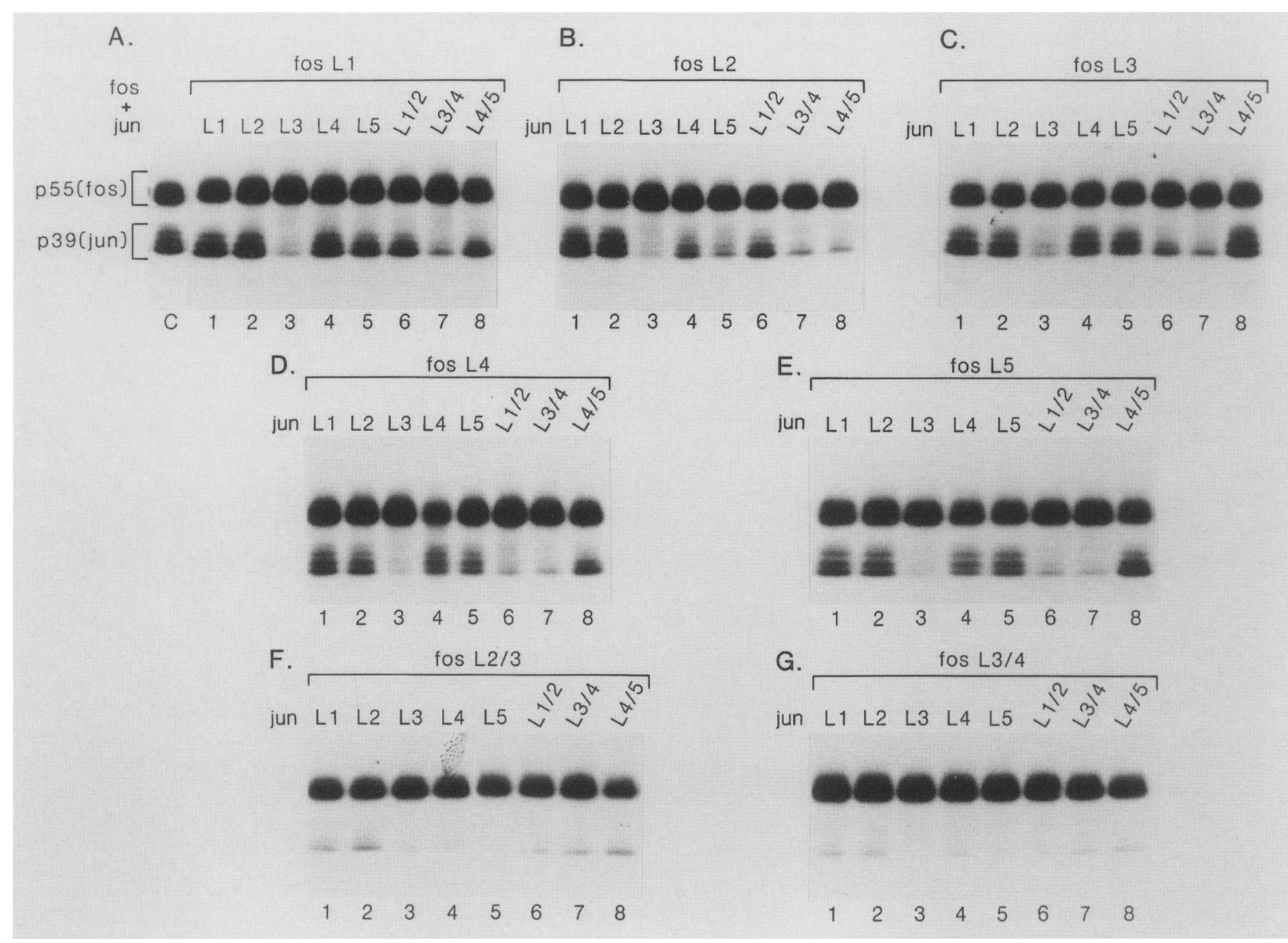

Figure 5. In vitro protein complex formation between mutant Fos and mutant Jun proteins. Labeled Fos and Jun wild-type and mutant proteins were synthesized in vitro, mixed, and immunoprecipitated with Fos M2 antibody as in Fig. 2. $(A)(\mathrm{Lane} C)$ Control lane contains $5 \mu \mathrm{l}$ each of Fos and Jun wild-type proteins; (lanes 1-8) $5 \mu \mathrm{l}$ of Fos Ll with $5 \mu \mathrm{l}$ of each Jun mutant, as depicted at the top of each panel. $(B)$ Fos L2 mutant assayed with each Jun mutant. $(C)$ Fos L3 mutant assayed with each Jun mutant. (D) Fos L4 assayed with each Jun mutant. $(E)$ Fos L5 assayed with each Jun mutant. $(F)$ Fos L2/3 assayed with each Jun mutant. $(G)$ Fos L3/4 assayed with each Jun mutant.

sults were surprising, but may be explained by a stabilization of complex formation in the presence of the TRE. Even more surprising, however, was the observation that Fos L2/3 could cooperate with Jun L2 at wild-type levels in DNA binding (Fig. 6F, cf. lane $\mathrm{C}$ and lane 2). The same observation was made with Fos L3/4 and Jun L4 (Fig. 6G, lane 4), suggesting that the mutations of both Fos Leu-179 (L2) and Leu-186 (L4) to valine, combined with the mutation of Jun Leu-304 (L4) to valine, provide an environment that is suitable for wild-type heterodimer formation in the presence of DNA.

A compilation of both protein association and the DNA-binding data is presented in Table 1.

\section{Discussion}

Gene transcription requires the binding of specific proteins to specific DNA sequences (Ptashne 1988). Modes of DNA-protein interaction include: (1) the helix-turnhelix motif (Pabo and Sauer 1984), (2) the zinc-finger- binding structure (Klug and Rhodes 1987), and (3) the recently identified leucine zipper (Landschultz et al. 1988a). In this paper we have explored the role and significance of individual leucine residues in the leucine zipper domain by studying the in vitro association of nuclear oncoproteins Fos and Jun and their binding affinities to TRE sequences.

\section{The leucine zipper is essential}

A salient feature of a number of DNA-binding proteins is a stretch of $\sim 30$ residues rich in basic amino acids, followed by a conserved heptad of leucine repeats (Landschulz et al. 1988a). Because of its positive charge, the proximal region may interact with DNA, whereas the distal region is hypothesized to be involved in dimerization through the formation of a long $\alpha$-helix. One member of this group of proteins is the yeast transcription factor, GCN4, which shares homology with 
Ransone et al.

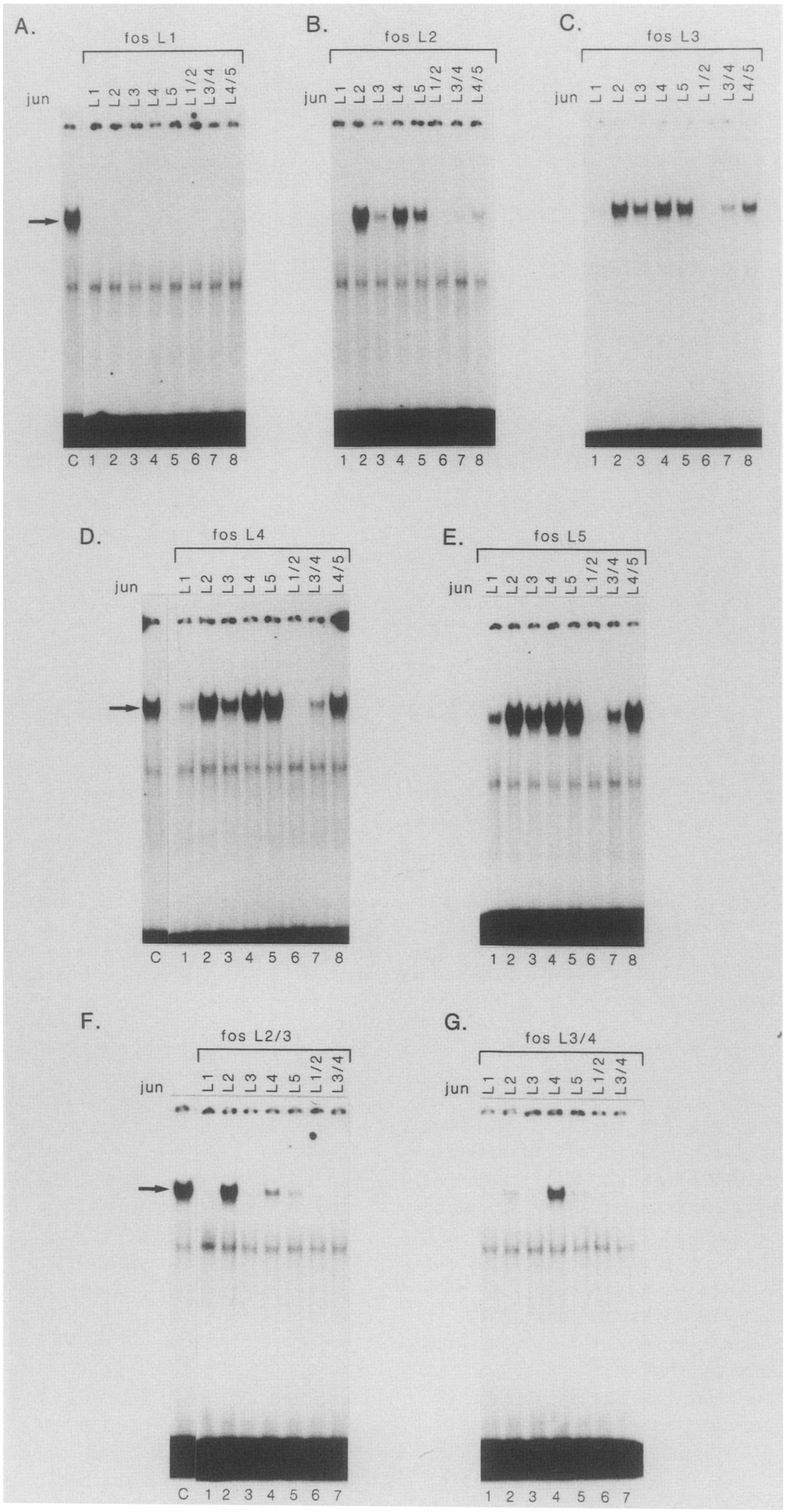

Figure 6. Specific DNA-binding activities of the various Fos and Jun mutant protein complexes. Unlabeled in vitro-translated proteins were assayed for binding to $10,000 \mathrm{cpm}$ of ${ }^{32} \mathrm{P}$-labeled TRE by gel retardation analysis. (Lanes $C$ ) Control using $2 \mu 1$ of each Fos and Jun wild-type proteins. $(A)$ Fos L1 mutant assayed with each Jun mutant; $(B)$ Fos L2 mutant assayed with each Jun mutant; $(C)$ Fos L3 mutant assayed with each Jun mutant; $(D)$ Fos L4 mutant assayed with each Jun mutant; $(E)$ Fos L5 assayed with each Jun mutant; $(F)$ Fos L2/3 asssayed with each Jun mutant, as indicated; $(G)$ Fos L3/4 assayed with each Jun mutant, as indicated. 


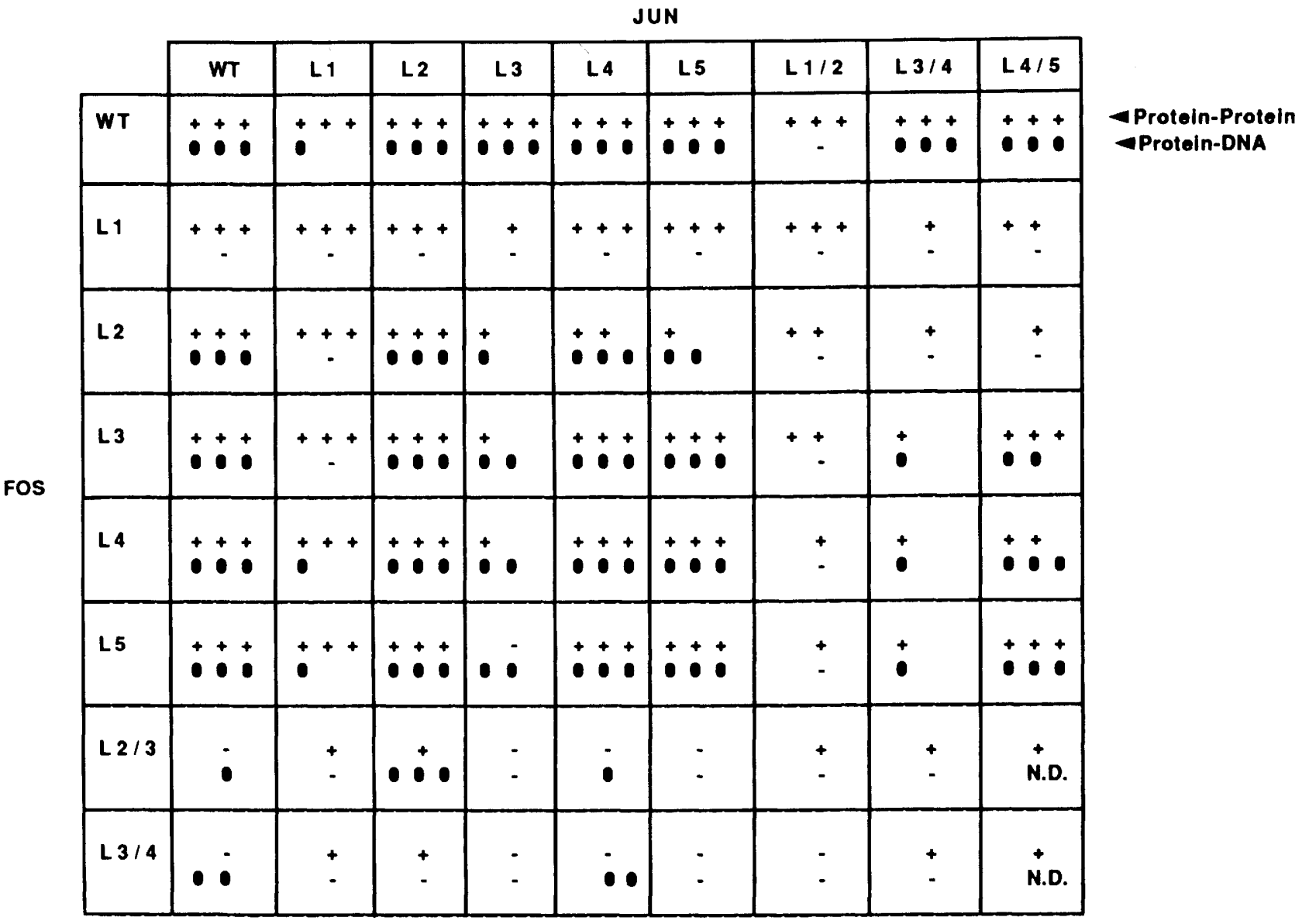

Data are compiled from results shown in Figs. 3-6. Symbols and abbreviations: (WT) wild type; $(+++\mid$ wild-type protein-protein interaction; $|++| 25 \%$ of wild type $;|+| 2-5 \%$ of wild type; $(\bullet \bullet \bullet)$ wild-type protein-DNA binding; $(\bullet \bullet) 25 \%$ of wild type; $(\bullet) 2-5 \%$ of wild type; (-) no binding; (N.D.) not done.

Jun/AP-1 (Vogt et al. 1987). GCN4 has been shown to bind DNA as a dimer (Hope and Struhl 1987). The basic region and leucine zipper domains of the protein are sufficient for dimerization and DNA-binding activity. Although GCN4 has been shown only to form homodimeric complexes, Jun, a protein with similar structural characteristics, can form both homodimeric and heterodimeric complexes (Halazonetis et al. 1988; Nakabeppu et al. 1988). Our results demonstrate that the proteinbinding domain of these two molecules can be localized to the leucine zipper region, because removal of the leucine repeat region from either Fos (Sassone-Corsi et al. $1988 \mathrm{c}$ ) or Jun [Jun $\Delta(\mathrm{L} 1-\mathrm{L} 5)$ Fig. 3B, lane 3] abolished the association of the two proteins. Mutagenic analysis of the Fos and Jun leucine zipper structure presented here (summarized in Table 1), provides evidence that the integrity of the leucines is essential for heterodimer formation in support of the leucine zipper model. This analysis also suggests that the hydrophobic interactions in the Fos leucine repeat are stable enough to overcome a single amino acid change in any one of the Fos leucine residues. However, when two consecutive leucines in Fos are mutated, the complex with Jun is no longer stable (Fig. 3A). It should be stressed that all of the mutations made were conservative changes from leucine to valine, which should not significantly alter the structure of the surrounding residues. On the other hand, Kouzarides and Ziff (1988), made more drastic mutations in the second through the fourth residues of the Fos leucine zipper domain with similar results. They changed the leucine residues L2 and L4 to isoleucine and L3 to arginine, yet complex formation was only affected when two consecutive mutations were introduced.

\section{The Iun leucine zipper is less sensitive to mutations}

When these site-specific mutations were made in the Jun protein, we expected the results to be similar to that 
of the Fos protein, as the site of Fos-Jun interaction was assumed to be through the interdigitation or the hydrophobic interactions between the leucines. However, any two mutations in the Jun leucine repeat had no affect on the ability of these proteins to form an immunoprecipitable complex with Fos (Fig. 3B), suggesting that the leucine zipper in Jun is more resistant to disruption. Like GCN4 (but not Fos), the Jun leucine zipper possesses several hydrophobic residues between the leucines. These may add to the stability of hetero- and homodimers formed by Jun. In fact, the only time a Jun mutant did not display wild-type protein-binding activity was when it was mixed with another Fos mutant (see binding matrix, Table 1). Under these circumstances, the Jun L3 is the only mutant that affected protein complex formation with Fos. However, the Jun L3 mutant did not abolish its ability to form a homodimer (J. Visvader, L. Ransone, and I.M. Verma, unpubl.). On the other hand, the Jun double mutants displayed various protein- and DNA-binding affinities for the different Fos mutant proteins (Fig. 5; Table 1). The binding activity in these proteins ranged from wild-type levels to $<5 \%$ of wild-type levels. In the case of the Fos protein, double mutations abolished the ability to form heterodimers with wild-type Jun, which is in contrast to the double mutants of Jun. These results suggest that the association between Fos and Jun is not simply due to the interdigitation of leucine residues but may be more dependent on the neighboring hydrophobic or charged residues.

\section{Fos $L 1$ and Jun L1 influence DNA binding}

Mutations in L1 of either Fos or Jun (Fos Leu-165; Jun Leu-283, Fig. 1) showed no detrimental effect on heterodimer (Fig. 3) or homodimer formation (J. Visvader, L. Ransone, and I.M. Verma, unpubl.) but severely curtailed binding to the TRE (Fig. 4). In a recent paper (Schuermann et al. 1989) it was shown that the mutation in the first leucine of $\mathrm{v}$-Fos prevented protein complex formation with Jun. We have no explanation for this discrepancy with the results shown in Figure 2A. A common feature of both the Fos and Jun Ll residue is that they are preceded by a region of basic residues (in Fos, van Straaten et al. 1983; in Jun, Lamph et al. 1988). A survey of all proteins containing a leucine zipper domain shows the conservation of the basic region motif (Hoeffler et al. 1988; Kouzarides and Ziff 1988; Landschultz et al. 1988a, M. Montminy, pers. comm.). It has been proposed that the basic region of Fos and Jun may be involved in DNA binding (Kouzarides and Ziff 1988; S. McKnight, pers. comm.). It is therefore not surprising that mutation of the first leucine of both proteins influences DNA binding. Thus, it is tempting to speculate that the role of the leucine zipper is to form a Fos and Jun heterodimer so that the basic regions are juxtaposed with each other to facilitate binding to the TRE. The Jun protein can form a homodimer to achieve essentially the same function, but it appears that Jun homodimers only bind weakly to the TRE (Halazonetis et al. 1988; Naka- beppu et al. 1988; Sassone-Corsi et al. 1988b,c). In contrast, Jun-Fos heterodimers bind at least 10- to 100-fold more avidly to TRE sequences (Halazonetis et al. 1988; Kouzarides and Ziff 1988; Nakabeppu et al. 1988; Sassone-Corsi et al. 1988c; Rauscher et al. 1989). Other leucine-zipper-containing proteins, such as GCN4 (Hope and Struhl 1987), and the enhancer binding protein C/EBP (Landschultz et al. 1988b) can bind to their cognate DNA motifs efficiently as homodimers and thus may not require heterodimer formation with other proteins.

\section{Are Fos-Jun heterodimers in a parallel or antiparallel orientation?}

It is not clear whether the formation of Fos-Jun heterodimers requires the two protein chains to be in a parallel or antiparallel orientation. Data in Table 1 showing that both the Fos L1 and Jun L1 mutants prevent binding of the complex to DNA without affecting protein-protein association would favor the formation of a heterodimer by parallel orientation of the two chains. We imagine that the leucine zipper domain is required to juxtapose the two proteins so that their basic regions present immediately upstream (Fig. 1) can be aligned. The basic region of the two proteins most likely interacts with the palindromic AP-1 site, a notion lent credence by the observation that mutations in the basic region of the Fos protein abolish the DNA-binding affinity of the heterodimer (Kouzarides and Ziff 1988). In an antiparallel orientation one might have expected that mutation of L5 would have had an adverse effect on DNA binding, but data presented in the binding matrix (Table 1) indicate no such effect. Recently, O'Shea et al. (1989) synthesized and characterized a peptide corresponding to the leucine zipper region of GCN4. They demonstrated that this peptide associates in the micromolar concentration range to form a stable dimer of $\alpha$-helices with a parallel orientation. More precise physicochemical means, however, are required to determine unambiguously the orientation of the Jun and Fos proteins.

\section{What promotes dimer formation?}

Does the specificity to form dimers (homo- or heterodimers) lie in the sequences within the leucine residues of leucine zipper domains, or are other regions contributing factors? Clearly, the mere presence of the leucine heptad repeat is not sufficient because Fos is unable to form homodimers (Halazontis et al. 1988; Nakabeppu et al. 1988). Similarly, the basic regions are unlikely to be significant contributing factors because mutations in this region do not affect heterodimer formation (Kouzarides and Ziff 1988). Furthermore, a severely truncated form of Fos (containing a 92-amino-acid core) can still form heterodimers with a truncated Jun protein (133 amino acids), further delineating the region of the proteins involved in dimer formation (Kouzarides and Ziff 1988). Additionally, Fos can form heterodimers with c-Jun and JunB, which share $<50 \%$ sequence identities 
but are nearly $80 \%$ identical in the leucine zipper domain (Ryder and Nathans 1988). Similarly, Fos and fra-1, which both bind to AP-1/Jun, share only $47 \%$ amino acid sequence identity but display $\sim 80 \%$ amino acid identity in the leucine zipper domain /Cohen and Curran 1988). Also, we have cotranslated in vitro-synthesized fos RNA with in vitro-synthesized GCN4, cAMP response element binding protein (CREB) c-myc RNA and detected no formation of heterodimers (V. Dwarki, L. Ransone, and M. Montminy, unpubl.). Similarly, Jun does not form heterodimers with GCN4 or CREB (V. Dwarki, L. Ransone, and M. Montminy, unpubl.). We therefore, believe that the sequences within the leucine zipper domain provide specificity for dimerization.

The position of leucine residues is invariant in nearly a dozen leucine-zipper-containing proteins so far identified (Kouzarides and Ziff 1988; Landschultz et al. 1988a; McKnight, pers. comm.), yet our data suggests that the leucine residues can undergo a conservative change to valine at a number of positions without adversely affecting either protein-protein or protein-DNA binding. One might have expected that if such mutations were inconsequential, they would have occurred in nature. One possibility is that our assay system is not sensitive enough to determine subtle changes in protein-protein or protein-DNA interactions. Perhaps the influence of physical parameters such as temperature, salt, etc., on dimer formation or protein-DNA binding would be revealing. Alternatively, the in vivo effect of mutating individual leucine residues may be quite profound. In fact, the results obtained by Schuermann et al. (1989) show that mutation in the Fos leucine zipper can influence its ability to trans-activate TRE in collaboration with Jun protein.

\section{Experimental procedures}

\section{Plasmids}

Standard DNA recombinant methodology was employed (Maniatis et al. 1982). The isolation and characterization of the fulllength cDNA clone of human c-fos (van Straaten et al. 1983; W.W. Lamph, unpubl.) and murine c-jun has been described (Lamph et al. 1988). The respective full-length cDNA sequences were subcloned into pGEM4 (Promega) and placed under the control of the bacteriophage $\mathrm{T} 7$ promoter, as was described previously (Sassone-Corsi 1988c).

Oligonucleotide-directed mutagenesis was used to generate site-specific mutants in the Fos and Jun leucine zipper domain (Kunkel 1985). A PstI jun cDNA fragment excised from pGEM4 was cloned into $\mathrm{M} 13 \mathrm{mp} 19$ in the negative orientation. Five oligodeoxynucleotides complementary to the regions containing the specific leucines to be altered were synthesized. The sequences of the oligodeoxynucleotides are:

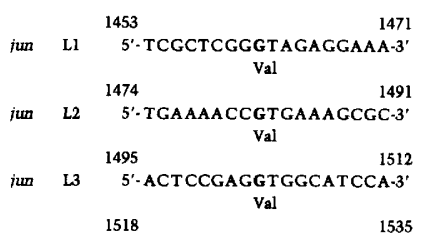

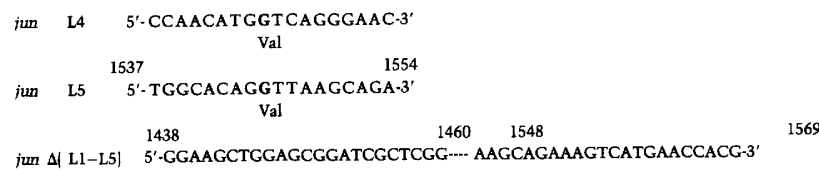

Two to three picomoles of each oligonucleotide was hybridized to 0.1 pmole of uracil containing DNA, which was prepared as described by passage of the phage through CJ236, an Escherichia coli strain that contains the dut, ung double mutation (Kunkel 1985). The complementary strand of DNA was synthesized in the presence of T4 DNA polymerase and T4 DNA ligase. The double-stranded DNA was transformed into competent MV1190 cells (Bio-Rad), and plaques were isolated and screened by sequencing using the Sequenase kit (U.S. Biochemicals). The annealing of the Jun $\Delta(\mathrm{L} 1-\mathrm{L} 5)$ oligonucleotide (a 45 mer that contains sequences on either side of the leucine zipper) to the jun M13 DNA resulted in an in-frame deletion of the entire Jun leucine zipper domain. The double mutations were generated in the same manner using the single-site M13 mutant templates, which were annealed to the appropriate mutated oligonucleotides.

The Fos mutations were prepared in the same manner as described above, except that the NaeI fragment of the fos cDNA was subcloned into $S \mathrm{maI}$ cleaved M13mp18 in the positive orientation. The following oligonucletides were prepared for mutagenesis:

fos $\mathbf{L} 1$

1959

1975

fos $\mathbf{L} 2$ 2091 2107

fos 3 3'-GTCTGG TTCATCTTCTA-5

fos L3 2113 2129

fos L4 3'-TCAGACGACACGTCTGG-5

fos L5 2134 2150 3'-AACGGT TGCACGACTTC-5 2155 2171

Phage were screened by sequencing, and the Nael fragment of positive clones was inserted into the SmaI site of pGEM3.

\section{In vitro transcription and translation}

Prior to in vitro transcription, all plasmids were linearized with EcoRI or BamHI. Two micrograms of each linearized plasmid was transcribed in vitro using $\mathrm{T} 7$ polymerase in a final reaction volume of $100 \mu \mathrm{l}$, as described previously (Sassone-Corsi et al. $1988 \mathrm{c})$. After a $2-\mathrm{hr}$ incubation at $30^{\circ} \mathrm{C}$, RQ1 DNase was added to a concentration of 1 unit per microgram of DNA, and the reaction was incubated for an additional $20 \mathrm{~min}$. The mRNA was extracted with phenol and then with chloroform, precipitated with ethanol and sodium acetate, and resuspended in half the original reaction volume.

RNA was translated in vitro with a micrococcal nucleasetreated, methionine-free rabbit reticulocyte lysate in a $50-\mu \mathrm{l}$ reaction volume, as directed by the supplier (Promega). Translation products were stored at $-80^{\circ} \mathrm{C}$. Translation products labeled with $\left[{ }^{35} \mathrm{~S}\right]$ methionine were analyzed by SDS-PAGE $(12.5 \%)$, as described by Laemmli (1970). Prestained high-molecular-weight markers (Bethesda Research Laboratories) were used for molecular weight standards. After electrophoresis, the gel was fixed with $10 \%$ acetic acid $/ 30 \%$ methanol, treated with $1 \mathrm{M}$ salicylic acid (Sigma), and autoradiographed.

In vitro association of Fos and lun

For in vitro protein-binding assays, equal volumes of reticulocyte lysate $\left(5 \mu \mathrm{l}\right.$ each) containing ${ }^{35}$ S $]$ methionine-labeled Fos or 
Jun proteins were combined and incubated at $30^{\circ} \mathrm{C}$ for $30 \mathrm{~min}$, as described by Sassone-Corsi et al. (1988c). Protein complexes were then mixed with $1 \mu \mathrm{l}$ of Fos M2 antibody (Curran et al. 1985 ) or anti-Fos monoclonal antibodies $18 \mathrm{H} 6$ or $14 \mathrm{Cl}$ (DeTogni et al. 1988), as indicated. The antigen-antibody complexes were collected by the addition of Pansorbin /Calbiochem-Behring), and the immunocomplexes were washed in RIPA buffer [10 mM Tris- $\mathrm{Cl}$ (pH 7.5), $150 \mathrm{~mm} \mathrm{NaCl}, 1 \% \mathrm{NP}-40$, $1 \%$ deoxycholate, $0.1 \%$ SDS] and prepared for SDS-PAGE as described (Barber and Verma 1987). The immunoprecipitated proteins were separated on $12.5 \%$ gels and prepared for autoradiography as described above.

\section{Gel shift analysis}

Gel retardation assays were performed as described (SassoneCorsi et al. 1988c). Two microliters of the in vitro-translated proteins was incubated with $2 \mu \mathrm{g}$ of poly[d(I-C)] (BoehringerMannheim) in TM buffer [50 mM Tris- $\mathrm{HCl}(\mathrm{pH} 7.9), 12.5 \mathrm{~mm}$ $\mathrm{MgCl}_{2}, 1 \mathrm{mM}$ EDTA, $1 \mathrm{mM}$ dithiothreitol, 20\% glycerol] for 20 $\mathrm{min}$ at room temperature in a $20-\mu \mathrm{l}$ final volume. A synthetic 18-bp oligonucleotide containing the human methallothionein IIA TRE (5'-AGCTTGATGAGTCAGCCG-3') was end-labeled with $\left[\gamma^{-32} \mathrm{P}\right] \mathrm{ATP}$, with $\mathrm{T} 4$ polynucleotide kinase. Approximately $0.1 \mathrm{ng}$ of ${ }^{32} \mathrm{P}$-labeled DNA $<10,000 \mathrm{cpm}$ / was added to the preincubated proteins. DNA-protein complexes were resolved on a $4 \%$ polyacrylamide gel $(38: 2$ acrylamide/bis-acrylamide $)$ in $0.25 \times \mathrm{TBE}[1 \times \mathrm{TBE}=50 \mathrm{mM}$ Tris-borate $(\mathrm{pH} 8.3), 1$ mM EDTA]. The gels were dried and autoradiographed with intensifying screens at $-70^{\circ} \mathrm{C}$.

\section{Acknowledgments}

We thank R. Doolittle, A. Klug, L. Orgel, Francis Crick, and S. McKnight for helpful discussions and W. Lamph for critical reading of the manuscript. We thank $P$. McClintock for help in preparation of this manuscript. L.J.R. is supported by postdoctoral training grant CA-08585-01. J.V. is supported by a Jane Coffin Childs Memorial Fund Fellowship. P.S.-C. is supported by a grant from the American Cancer Society (ACS) and is on leave of absence from CNRS, France. This work was supported by grants from the National Institutes of Health and ACS to I.M.V.

\section{References}

Angel, P., E.A. Allegretto, S.T. Okino, K. Hattori, W.J. Boyle, T. Hunter, and M. Karin. 1988. Oncogene jun encodes a sequence-specific trans-activator similar to AP-1. Nature 332 166-171.

Angel, P., M. Imagawa, R. Chiu, B. Stein, R.J. Imbra, H.J. Rahmsdorf, C. Jonat, P. Herrlich, and M. Karin. 1987. Phorbol ester-inducible genes contain a common cis element recognized by a TPA-modulated trans-acting factor. Cell 49: 729-739.

Barber, J.R. and I.M. Verma. 1987. Modification of Fos proteins: Phosphorylation of c-Fos but not v-Fos is stimulated by TPA and serum. Mol. Cell. Biol. 7: 2201-2211.

Bohmann, D., T.J. Bos, A. Admon, T. Nishimura, P.K. Vogt, and R. Tjian. 1987. Human proto-oncogene c-jun encodes a DNA binding protein with structural and functional properties of transcription factor AP-1. Science 238: 1386-1392.

Bos, T.J., D. Bohmann, H. Tsuchie, R. Tjian, and P.K. Vogt. 1988. v-jun encodes a nuclear protein with enhancer binding activities of AP-1. Cell 52: 705-712.
Chiu, R., W.J. Boyle, J. Meek, T. Smeal, T. Hunter, and M. Karin. 1988. The c-fos protein interacts with c-jun/AP-1 to stimulate transcription of $\mathrm{AP}-1$ responsive genes. Cell 54: $541-552$.

Cohen, D.R. and T. Curran. 1988, fra-1: A serum-inducible, cellular immediate early gene that encodes a fos-related antigen. Mol. Cell. Biol. 8: 2063-2069.

Curran, T. and N.M. Teich. 1982. Candidate product of the FBJmurine osteosarcoma virus oncogene: Characterization of a 55,000 dalton phosphoprotein. I. Virol. 42: 114-122.

Curran, T. and I.M. Verma. 1984. The FBR-murine osteosarcoma virus. I. Molecular analysis and characterization of a 75,000 gag-fos fusion product. Virology 135: 218-228.

Curran, T., A.D. Miller, L. Zokas, and I.M. Verma. 1984. Viral and cellular Fos proteins: a comparative analysis. Cell 36: $259-268$.

Curran, T., C. Van Beveren, N. Ling, and I.M. Verma. 1985. Viral and cellular Fos proteins are complexed with a 39,000 cellular protein. Mol. Cell. Biol. 5: 167-172.

Curran, T., G. Peters, C. Van Beveren, N.M. Teich, and I.M. Verma. 1982. FBJ-murine osteosarcoma virus: Identification and molecular cloning of biologically active proviral DNA. I. Virol. 44: 674-682.

De Togni, P., H. Niman, V. Raymond, P. Sawchenko, and I.M. Verma. 1988. Detection of Fos protein during osteogenesis by monoclonal antiboties. Mol. Cell. Biol. 8: 2251-2256.

Distel, R.J., H.-S. Ro, B.S. Rosen, D.L. Groves, and B.M. Spiegelman. 1987. Nucleoprotein complexes that regulate gene expression in adipocyte differentiation: Direct participatieon of c-fos. Cell 49: 835-844.

Franza, B.R., Jr., F.J. Rauscher, III, S.F. Josephs, and T. Curran. 1988. The Fos complex and Fos-related antigens recognize sequence elements that contain AP-1 binding sites. Science 239: 1150-1153.

Halazonetis, T.D., K. Georgopoulos, M.E. Greenberg, and P. Leder. 1988. c-jun dimerizes with itself and with c-fos, forming complexes of different binding affinities. Cell 55: 917-924.

Harshman, K.D., W.S. Moye-Rowley, and C. Parker. 1988. Transcriptional activation by the SV40 AP-1 recognition element in yeast is mediated by a factor similar to AP-1 that is distinct from GCN4. Cell 53: 321-330.

Hoeffler, J.P., T.E. Meyer, Y. Yun, J.L. Jameson, and J.F. Habener. 1988. Cyclic AMP-responsive DNA-binding protein: Structure based on a cloned placental cDNA. Science 242: $1430-1433$.

Hope, I.A. and K. Struhl. 1987. GCN4, a eukaryotic transcriptional activator protein, binds as a dimer to target DNA. EMBO J. 6: 2781-2784.

Jones, R.H., R. Moreno, P. Nurse, and N.C. Jones. 1988. Expression of the SV40 promoter in fission yeast: Identification and characterization of an AP-1-like factor. Cell 53: 659667.

Klug, A. and R. Rhodes. 1987. Zinc fingers: A novel protein motif for nucleic acid recognition. Trends Biol. 12: 464469.

Kouzarides, T. and E. Ziff. 1988. The role of the leucine zipper in the Fos-Jun interaction. Nature 336: 646-651.

Kunkel, T.A. 1985. Rapid and efficient site-specific mutagenesis without phenotypic selection. Proc. Natl. Acad. Sci. 82: 488-492.

Laemmli, U.K. 1970. Cleavage of structural proteins during assembly of the head of bacteriophage T4. Nature 277: 680685.

Lamph, W.W., P. Wamsley, P. Sassone-Corsi, and I.M. Verma. 1988. Induction of proto-oncogene jun/AP-1 by serum and TPA. Nature 334: 629-631. 
Landschultz, W.H., P.F. Johnson, and S.L. McKnight. 1988a. The leucine zipper protein: A hypothetical structure common to a new class of DNA binding proteins. Science 240: 1759-1764.

Landschultz, W.H., P.F. Johnson, E.Y. Adashi, B.J. Graves, and S.L. McKnight. 1988b. Isolation of a recombinant copy of the gene encoding C/EBp/ Genes. Dev. 2: 786-800.

Lee, W., P. Mitchell, and R. Tjian. 1987a. Purified transcription factor AP-1 interacts with TPA-inducible enhancer elements. Cell 49: 741-752.

Lee, W., A. Haslinger, M. Karin, and R. Tjian. 1987b. Activation of transcription by two factors that bind promoter and enhancer sequences of the human metallothionein gene and SV40. Nature 325: 368-372.

Lucibello, F.C., M. Newberg, J.B. Hunter, T. Jenuwein, M. Schuermann, R. Wallich, B. Stein, A. Schonthal, P. Herrlich, and R. Muller. 1988. Transactivation of gene expression by fos protein: Involvement of a binding site for the transcription factor AP-1. Oncogene 3: 43-51.

Maki, Y., T.J. Bos, C. Davis, M. Starbuck, and P.K. Vogt. 1987. Avian sarcoma virus 17 carries the jun oncogene. Proc. Natl. Acad. Sci. 84: 2848-2852.

Maniatis, T., E.F. Fritsch, and J. Sambrook. 1982. Molecular cloning: A laboratory manual. Cold Spring Harbor Laboratory, Cold Spring Harbor, New York.

Nakabeppu, Y., K. Ryder, and D. Nathans. 1988. DNA binding activities of three murine jun proteins: stimulation by fos. Cell 55: 907-915.

O'Shea, E.K., R. Rutkowski, and P.S. Kim. 1989. Evidence that the Leucine Zipper is a coiled coil. Science 243: 538-542.

Pabo, C.O. and R.T. Sauer. 1984. Protein-DNA recognition. Annu. Rev. Biochem 53: 293-321.

Piette, J. and M. Yaniv. 1987. Two different factors bind to the domain of the polyoma virus enhancer, one of which also interacts with the SV40 and c-fos enhancers. EMBO $J$. 6: $1331-1337$.

Ptashne, M. 1988. How eukaryotic transcriptional activators work. Nature 335: 683-689.

Rauscher, F.J., III, P.J. Voulalas, B.R. Franza, and T. Curran. 1988a. Fos and Jun bind cooperatively to the AP-1 site: Reconstitution in vitro. Genes Dev. 2: 1687-1699.

Rauscher, F.J., III, L.C. Sambucetti, T. Curran, R.J. Distel, and B. Spiegelman. 1989. A common DNA binding site for Fos protein complexes and transcription factor AP-1. Cell 52: 471-480.

Rauscher, F.J., III, D.R. Cohen, T. Curran, T.J. Bos, P.K. Vogt, D. Bohmann, R. Tkian, and B.R. Franza, Ir. 1988b. Fos associated protein $\mathrm{p} 39$ is the product of the jun proto-oncogene. Science 240: 1010-1016.

Ryder, K., L.F. Lau, and D. Nathans. 1988. A gene activated by growth factors is related to the oncogene v-jun. Proc. Natl. Acad. Sci. 85: 1487-1491.

Ryseck, R.P., S.I. Hirai, M. Yaniv, and R. Bravo. 1988. Transcriptional activation of c-jun during the $G_{0} / G_{1}$ transition in mouse fibroblasts. Nature 344: 535-537.

Sassone-Corsi, P., J.C. Sisson, and I.M. Verma. 1988a. Transcriptional autoregulation of the proto-oncogene fos. Nature 334: 314-319.

Sassone-Corsi, P., W.W. Lamph, M. Kamps, and I.M. Verma. $1988 \mathrm{~b}$. fos-associated cellular p39 is related to nuclear transcription factor AP-1. Cell 54: 533-560.

Sassone-Corsi, P., L.J. Ransone, W.W. Lamph, and I.M. Verma. 1988c. Direct interaction between fos and jun nuclear oncoproteins: role of the leucine zipper domain. Nature 336: 692-695.

Schuermann, M., M. Neuberg, J.B. Hunter, T. Jenuwein, R.P. Ryseck, R. Bravo, and R. Muller. 1989. The leucine repeat motif in Fos protein mediates complex formation with Jun/ AP-1 and is required for transformation. Cell 56: 507-516.

Setoyama, C., R. Frunzio, G. Liau, M. Mudryi, and B. DeCrombrugghe. 1986. Transcriptional activation encoded by the v-fos gene. Proc. Natl. Acad. Sci. 83a: 3213-3217.

Struhl, K. 1987. The DNA binding domains of the jun oncoprotein and the yeast GCN4 transcriptional activator proteins are functionally homologous. Cell 50: 841-846.

1988. the jun oncoprotein, a vertebrate transcription factor, activates transcription in yeast. Nature 332: 649650.

van Straaten, F., R. Muller, T. Curran, C. Van Beveren, and I.M. Verma. 1983. Complete nucleotide sequence of human c-onc gene: Deduced amino acid sequence of the human c-fos protein. Proc. Natl. Acad. Sci. 80: 3183-3187.

Verma, I.M. 1986. Proto-oncogene fos: A multifaceted gene. Trends Genet. 2: 93-96.

Vogt, P.K., T.J. Bos, and R.F. Doolittle. 1987. Homology between the DNA-binding domain of the GCN4 regulatory protein of yeast and the carboxy terminal region of a protein coded for by the oncogene jun. Proc. Natl. Acad. Sci. 84: 3316-3319. 


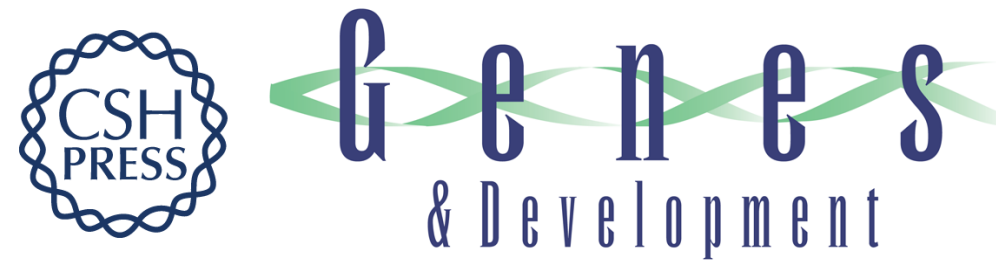

\section{Fos-Jun interaction: mutational analysis of the leucine zipper domain of both proteins.}

L J Ransone, J Visvader, P Sassone-Corsi, et al.

Genes Dev. 1989, 3:

Access the most recent version at doi:10.1101/gad.3.6.770

References This article cites 51 articles, 20 of which can be accessed free at:

http://genesdev.cshlp.org/content/3/6/770.full.html\#ref-list-1

License

Email Alerting Receive free email alerts when new articles cite this article - sign up in the box at the top Service right corner of the article or click here.

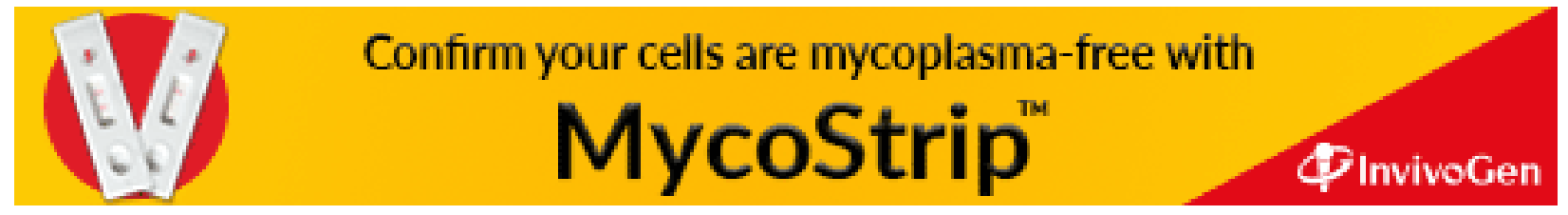

